\title{
Notary Role in Making Using Standard Contract Technology Information in The Framework of Legal Protection of Small and Medium Enterprises (SMEs)
}

\author{
Moch. Asep Rusmana1, Bambang Rudi Hartoko ${ }^{2}$ and Gunarto ${ }^{3}$
}

Abstract. The purpose of this research is; (1) to analyze the role of the notary in contract manufacturing standards using technology information in a business transaction that is carried out by SMEs, and (2) to analyze the obstacles and solutions contract manufacturing standards using technology information in providing legal protection to SMEs. Researchers use various types of data in the study, such as; (1) primary data, (2) secondary data, and (3) the data tertiary. The three types of data must be mutually supportive and have conformity with one another so that the results of this study can be justified scientifically.

The conclusion of this study, namely; (1) business contracts are usually carried out by SMEs in general do not engage the services of a notary. Form of the contract was generally not made in the format of a standard contract. In general, SMEs also do not use technology information in their business transactions. Only a small portion of SMEs that have used the services of a notary and technology information in conducting business transactions, (2) while the main obstacles SMEs have not been optimally use the services of a notary in the transaction business was due to cost factors (notary) who felt still quite burdensome, attributed to the relatively small volume of the SMEs business.

Keywords; Notary; Standard Contracts; Technology Information; Legal Protection and SMEs.

\section{Introduction}

Constitution of the State of Indonesia Of 1945 (UUD 1945), the written constitution of Indonesia, the fourth paragraph specifies that the purpose of the establishment of the state government of Indonesia is to hold the welfare of the entire people of Indonesia. It was understood that the implementation of the welfare of society as referred to 1945 was related to the economic activity in its various forms organized by the people of Indonesia. On the other hand the implementation of economic activity in a community to a certain degree be influenced by the culture of the community itself, and then the culture of a society is also in fact strongly influenced by religion or beliefs held public question.

History proves that there is a close link between the existence of the Islamic religion with trading activities. Prophet Muhammad during his youth was known as a merchant, as well as the Caliph Abu Bakr, which bertama of the four caliphs, known as a trader. Likewise, the spread of Islam throughout the world mostly done via the trade. The

\footnotetext{
${ }^{1}$ Students of Master of Notarial Law, Faculty of Law, Universitas Islam Sultan Agung email a email: aryawiza.cv@gmail.com

2 Students of Master of Law, Faculty of Law, Universitas Islam Sultan Agung email rudikennymahesa@gmail.com

${ }^{3}$ Professor in Faculty of Law UNISSULA Semarang
} 
linkage between the religion of Islam with the trade confirmed again by the several statements in the Qur'an and in the hadith about trade issues ${ }^{4}$,

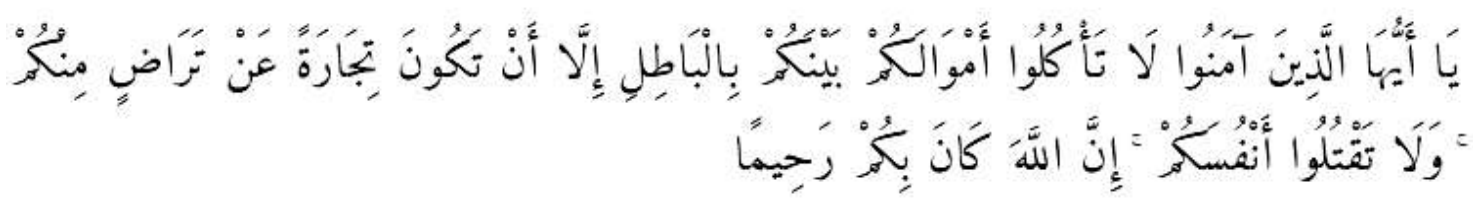

"O ye who believe, do not eat each other neighbor's property by way of vanity, except by way of commerce that goes with the same love-love between you. "(Surat an-Nisa': 29)

Hadith narrated by Abu Hurairah: "That Prophet pbuh., prohibiting the sale and purchase system mulamasah (compulsory purchase if the buyer has touched the merchandise) and munabadzah (barter system between two people by throwing their merchandise without verifying it)." (HR. Bukhari and Muslim).

Currently existing entrepreneurs in Indonesia is estimated to reach $3.1 \%$ of the total population of Indonesia. In countries that have first developed, the current number of wirausahawannya reached $14 \%{ }^{5}$, It can give you an idea that even though the number of entrepreneurs in Indonesia continues to increase, but the increase is far below countries that are already developed, so it should be increased again. It is currently estimated there are about 59 million independent business people in Indonesia which $99 \%$ are SMEs. History proves that SMEs have the ability to withstand the economic crisis, it is evident at a time of economic crisis in Indonesia in 1998. In 2015 ago, where the rate of the world economy slowing down, at the same time SMEs can still grow consistently. ${ }^{6}$

The ability of SMEs to overcome the economic crisis by the Chairman of the Board of Directors CIDES (Center for Information and Development Studies) is caused by three things: ${ }^{7} ;$ (1) SMEs generally produce goods and services close to people's needs, (2) SMEs using a resource that is local, and (3) capital SMEs generally do not rely on banking.

Nowadays, the development of SMEs is inseparable from the development of technology information as a means (instrument) to reconcile between the seller of goods / services to the buyer of goods / services. With the technology information gap between sellers and buyers are no longer far away, only limited by the speed and

4 Teras Aksara 26 June 2013 Ayat \& Hadits Ekonomi Tentang Perdagangan (simple version),http://terasaksara.blogspot.com/2013/06/ayat-hadits-ekonomi-tentang-

perdagangan.html Accessed on October 92018.

${ }^{5}$ Kompas.com 5 April 2018 Jumlah Entrepreneur di Indonesia Jauh di Bawah Negara Maju Ini Kata Jokowi https://nasional.kompas.com/read/2018/04/05/17261391/jumlah-entrepreneur-diindonesia-jauh-di-bawah-negara-maju-ini-kata-jokowi Accessed on October 12018.

${ }^{6}$ OkezoneFinance 25 January 2016 Hebatnya UMKM Tahan Krisis Hingga Serap Banyak Pekerja https://economy.okezone.com/read/2016/01/25/320/1296249/hebatnya-umkm-tahan-krisishingga-serap-banyak-pekerja, Accessed on October 12018.

Kompas.com 8 March 2012 Tiga Hal Yang Buat UMKM Tahan Krisis https://ekonomi.kompas.com/read/2012/03/28/11093274/Tiga.Hal.yang.Buat.UMKM.Tahan.Krisi s. Accessed on October 12018. 
capacity of the Internet used by the seller and the buyer. Technology information has made the boundaries between regions or between countries become imaginary boundaries that are located just above the map alone. In this case the law in terms of the legislation in many respects his position was replaced by the law in terms of the generally recognized customs. The shift characteristics such laws have been put in place legal certainty affected the dynamic of space and time.

Requirement of legal certainty in a contract sometimes inversely with the need for speed of doing business. For most businesses, legal certainty can only be seen as part of the complexity and expenditure budget into barrier of the speed of running the business. Although a certain level of understanding can be true, but the truth of the need for legal certainty which is born of a contract remains a real need for these businesses. Thus the need to compromise on the various stakeholders associated with it. Relevant stakeholders here include; (1) seller, (2) the buyer, (3) a notary, (4) a service provider of technology information services, and others.

\section{Research methods}

This study uses a method socio legal research approach, using a special primary data available for this study, which was obtained through interviews, observation or direct field observations conducted by researchers. Accordingly, this research is descriptive because it describes a condition that is being studied and describe the results of the research itself.

\section{Results and Discussion}

\subsection{Analysis of the role of the notary in contract manufacturing standards using technology information in a business transaction that is carried out by SMEs.}

What is meant by the Notary office is; "Public official authorized to make an authentic deed and other has authority referred to in this Act or under any other laws"8, In the Law of the Republic of Indonesia Number 30 Of 2004 regarding Notary and in the Law of the Republic of Indonesia Number 2 of 2014 on the Amendment of Act No. 30 of 2004 concerning Notary does not specifically mention the meaning or definition of "public office "the. Common Position Here is a translation of coined the term "openbare amtbtenaren" contained in Article 1868 of the Civil Code is an official who has the task relating to the public interest so-called public officials, namely; officials appointed by the government, and have certain authority associated with his role, which in this case is a notary office, in terms of doing service to the community ${ }^{9}$,

\footnotetext{
${ }^{8}$ Law of the Republic of Indonesia Number 2 of 2014 on the Amendment of Act No. 30 of 2004 concerning Notary Article 1 paragraph 1.

${ }^{9}$ Kristian Dwi Sancoko 7 November 2016 Notaris Sebagai Pejabat Umum Dan Jenis Notaris https://www.scribd.com/document/330236673/Notaris-Sebagai-Pejabat-Umum-Dan-Jenis-

Notaris Accessed on 20 November 2018.
} 
Notary authority of which is to create an authentic deed, that is an act which "conveys the formal correctness notified in accordance with what the parties to the Notary". ${ }^{10}$ The definition as to position the notary on the passive position because "only" waiting for notification of the parties only. Nevertheless notaries also have an obligation to "make sure that what is contained in the Deed truly understood and in accordance with the will of the parties, that is the way to read it so that it becomes clear the contents Deed, as well as provide access to information, including access to legislation related to the parties signatory to the deed. Thus, the parties may determine to be free to agree or disagree with the contents of Deed to be signed "11, Based on the description above can be understood that the authority of the office of the notary who tend to be passive that has been matched by obligations that are likely to be active in order to ensure certainty, order, and legal protection of the parties concerned with the product authentic act of the notary office.

Function or usefulness authentic act is as a proof of the strongest and most with an important role in any legal relationships that occur in people's lives, especially in business areas such as the business carried out by SMEs are a major part of business activities that exist in society. The legal relationship is primarily associated with the need for proof is written in a variety of business relationships, activities in the fields of banking, land, social activities, and others. With the authentic act as a product of the notary office is expected to clearly define the rights and obligations of the parties, and to ensure legal certainty, and also can prevent the dispute between the parties. In case of dispute between the parties for various reasons still occurs, then the authentic act can be used as written evidence of the strongest and fullest. Thus the authentic act as a product of the notary's office can provide a real contribution to the settlement (in particular civil cases) that occurred between the parties are cheap and fast.

As business activities in general, the business activities carried out by SMEs associated with the issue of the contract (agreement). Due to various reasons, contracts undertaken by SMEs is generally made orally (not written), so it should be assumed naturally less obtain adequate legal protection. In these conditions SMEs face a dilemma between necessary absence of legal protection in order to carry out its business activities through contracts / agreements, with the benefit of obtaining and retaining customers. In fact those two things do not always go hand in hand. At the time of the contract formalities be clear, the business becomes more complex activities of the administrative side. It became one of the triggers the shift of customers to other parties (business competitors) are on "administrative requirements" more modest. Based on the description above, the existence of a standard contract (Contract raw) become quite important that the parties that are part of the business activities of the protection and legal certainty, while at the other side of the "process" implementation is relatively simple, so do not be reason enough for customers to business move with the competitors.

\footnotetext{
${ }^{10}$ Law of the Republic of Indonesia Number 30 Of 2004 concerning Notary General Explanation of the fifth paragraph.

${ }^{11}$ Ibid.
} 
In simple terms is a standard contract here is an authentic deed made by the notary which by its nature or shape can be used in various circumstances flexibly. The standard contract thus only contain matters of a general nature and subject. It should be realized that with all the limitations of the standard contract can not provide certainty and legal protection is optimal, but it is still better than no contract at all.

The observation of researchers showed that the "habit" SMEs not (less) made a contract related to its business activities are influenced by several things, such as; (1) The transaction values the business activities of SMEs are relatively small so that there is no "budget" to make an authentic deed to a notary associated with the contract / business activities, (2) lack of knowledge relating to legal issues, and (3) the "administration" tends to be regarded as activities that are "complicated" and spend time.

The problems faced by SMEs due to the cost factor, knowledge, and time in the levels can be addressed by technology information. If the SMEs with a notary already met in cyberspace through technology information, the cost of obtaining an authentic deed factors associated with business contracts undertaken by SMEs can be suppressed (reduced) to the level that can be accepted by the perpetrators of these SMEs. Likewise related to adherence / compliance of the SMEs to the legislation in force can be further enhanced with the help of notaries who are connected through technology information.

\subsection{Analysis of barriers and solutions using a standard contract manufacturing of technology information in providing legal protection to SMEs.}

The application of a standard contract that is authentic act (notary office products) in the business transactions carried out by SMEs with the help of technology information course, is a relatively new idea. In a possible implementation obstacles, including:

- The barriers are cultural. Business transactions carried out by SMEs is generally made orally based on mutual trust. In the development, it can not provide legal protection and potentially cause business disputes. Over time, the necessary existence of a contract that is no certainty in the attempt. Because of the scope of the activities of SMEs are relatively small, the use of a standard contract is expected to provide legal protection for SMEs. The use of standard contracts traditionally also potentially cause difficulties because in fact the perpetrators of these SMEs may be in remote locations. It effectively can be overcome with the use of technology information can significantly close the gap between the perpetrators of these SMEs.

- Barriers to technology information. Maybe this time in a large enough portion, the SMEs are not derived from the millennial generation ${ }^{12}$ But comes from the generation

\footnotetext{
${ }^{12}$ Also called Generation Y Generation Me or Echo Boomers a generation born between the years 1980-1990 until the early 2000s. Ministry of Communication and Information of the Republic of Indonesia Know the Millennial Generation
} 
of Baby Boomers or Generation $X^{13}$, Parents of millennials. Rapid development of technology information occurred during the millennial generation. It was not fully followed by the previous generation, causing the gap (distance) between the mastery of technology generation $\mathrm{X}$ or the previous generation, with the needs of today's technology. One way to overcome the technological gap is through training, or other similar activities. The activities in question can be either formal or informal.

- Legal obstacles. As a public official, a notary public office are required to meet various provisions in the position. Legal provisions in the form of legislation ${ }^{14}$ and a code of ethics. ${ }^{15}$ The formalities are generally rigid. This is possible not in harmony with the nature of the technology information that is flexible. Need to do in-depth review of the conformity of the formalities of the law according to the notary office to do with the implementation of technology information in the life of everyday people of Indonesia, especially in business activity.

- Cost barriers. The business activities of the SMEs in general is synonymous with business activities "of low value / retail". It is not entirely true. There are various activities of SMEs "high value", one of which is associated with the activities of SMEs handicrafts for export markets. By using the assumption that the activities of SMEs "is small / retail", then the additional expenditure for the purposes of making a contract in the form of an authentic deed, the notary office products, actually be a counter-productive expenditure against activities of SMEs itself. Although it is realized that the existence of a contract is very important in the activities of SMEs so that its activities can obtain legal protection. One way to overcome this is by any standard contract that cost the cost of manufacture and can be used repeatedly but still have legal force as an authentic act which may give perfectly legal protection. In a certain extent it can be received achievement facilitated by technology information. What is meant by technology information here is not only related to its hardware, but also includes its software. What is meant by software here are not limited to computer programs, but also includes a set of laws and regulations What is meant by technology information here is not only related to its hardware, but also includes its software. What is meant by software here are not limited to computer programs, but also includes a set of laws and regulations What is meant by technology information here is not only related to its hardware, but also includes its software. What is meant by software here are not limited to computer programs, but also includes a set of laws and regulations ${ }^{16}$ which allows the technology information into a "media business" which are legal under the law.

https://www.kominfo.go.id/content/detail/8566/mengenal-generasi-millennial/0/sorotan_media Accessed on 21 November 2018.

${ }_{13}^{13}$ Wikipedia Millennial https://id.wikipedia.org/wiki/Milenial Accessed on 21 November 2018.

14 Law of the Republic of Indonesia Number 30 Of 2004 concerning jo Notary Law of the Republic of Indonesia Number 2 Of 2014 on the Amendment of Act No. 30 of 2004 concerning Notary.

${ }^{15}$ Code of conduct notary result Extraordinary Congress of Indonesian Notary Association in Banten on 29-30 May 2015.

${ }^{16}$ Law of the Republic of Indonesia Number 11 Of 2008 on Information and Electronic Transactions jo Law of the Republic of Indonesia Number 19 Of 2016 on the Amendment of Act No. 11 of 2008 on Information and Electronic Transactions. 


\section{Closing}

\subsection{Conclusion}

The conclusion of this study are as follows:

- Business contracts are usually carried out by SMEs in general do not engage the services of a notary. Form of the contract was generally not made in the format of a standard contract. In general, SMEs also do not use technology information in their business transactions. Only a small portion of SMEs that have used the services of a notary and technology information in conducting business transactions.

- There are four (4) main drag manufacture / use of a standard contract with the use of technology information by SMEs, namely:

- The barriers are cultural, such obstacles can be overcome by changing habits of business transactions orally be written.

- Barriers in technology information, these obstacles can be overcome by reducing or eliminating the gap (distance) mastery of technology information SMEs with the millennial generation technology through training and other similar activities.

- Legal obstacles, these obstacles can be overcome by means of reevaluation of the laws and professional codes of conduct or current associated with the office of a notary, and implementation of technology information in the context of business activities carried out by SMEs.

- Cost barriers, this barrier can be overcome by the manufacture or use of standard contracts in the activities of SMEs which are implemented by utilizing technology information with a set of hard ware and software her.

\subsection{Recommendations}

- The existence of synergy between the notary office professional organization with the authority that deal with SMEs through formal cooperation.

- The integration of the various legislations that allow SMEs obtain legal protection through the use of standardized contracts based on technology information.

\section{Bibliography}

[1] https://www.kominfo.go.id/content/detail/8566/mengenal-generasimillennial/0/sorotan media, Accessed on 21 November 2018.

[2] Kompas.com, 5 April 2018, Jumlah Entrepreneur di Indonesia Jauh di Bawah Negara Maju, Ini Kata Jokowi, https://nasional.kompas.com/read/2018/04/05/17261391/jumlah-entrepreneur-diindonesia-jauh-di-bawah-negara-maju-ini-kata-jokowi, Accessed on October 1, 2018.

[3] Kompas.com, 8 March 2012, Tiga Hal Yang Buat UMKM Tahan Krisis, https://ekonomi.kompas.com/read/2012/03/28/11093274/Tiga.Hal.yang.Buat.UMK M.Tahan.Krisis., Accessed on October 1, 2018. 
[4] Kristian Dwi Sancoko, 7 November 2016, Notaris Sebagai Pejabat Umum Dan Jenis Notaris, https://www.scribd.com/document/330236673/Notaris-Sebagai-PejabatUmum-Dan-Jenis-Notaris, Accessed on 20 November 2018.

[5] OkezoneFinance, 25 January 2016, Hebatnya UMKM, Tahan Krisis Hingga Serap Banyak Pekerja, https://economy.okezone.com/read/2016/01/25/320/1296249/hebatnya-umkmtahan-krisis-hingga-serap-banyak-pekerja, Accessed on October 1, 2018.

[6] Teras Aksara, 26 June 2013, Ayat \& Hadits Ekonomi Tentang Perdagangan (simple version),http://terasaksara.blogspot.com/2013/06/ayat-hadits-ekonomi-tentangperdagangan.html, Accessed on October 9, 2018.

[7] Wikipedia, Millennial, https://id.wikipedia.org/wiki/Milenial, Accessed on 21 November 2018.

[8] Law of the Republic of Indonesia Number 11 Of 2008 on Information and Electronic Transactions jo Law of the Republic of Indonesia Number 19 Of 2016 on the Amendment of Act No. 11 of 2008 on Information and Electronic Transactions.

[9] Law of the Republic of Indonesia Number 2 of 2014 on the Amendment of Act No. 30 of 2004 concerning Notary, Article 1 paragraph 1.

[10] Law of the Republic of Indonesia Number 30 Of 2004 concerning jo Notary Law of the Republic of Indonesia Number 2 Of 2014 on the Amendment of Act No. 30 of 2004 concerning Notary.

[11]Law of the Republic of Indonesia Number 30 Of 2004 concerning Notary, General Explanation of the fifth paragraph. 